\title{
THE CHARTER: A NEW ROLE FOR THE JUDICIARY?
}

\author{
MADAME JUSTICE B.M. MCLACHLIN ${ }^{*}$
}

The Honourable Madame Justice McLachlin, in this transcript of her presentation of the Weir Memorial Lecture, discusses the fundamental change in the role of the Canadian courts brought about the adoption of the Canadian Charter of Rights and Freedoms and how they should go about discharging the new responsibilities which the Charter has placed upon them. Madame Justice McLachlin begins by considering the previously unlitigable range of social and moral questions which are now confronting the Canadian courts and the difficulties that this is causing in judicial decision-making due to the absence of precedent, the open-textured language of the Charter and the necessity of making value-based decisions. In addressing these problems, Madame Justice McLachlin suggests that first, the courts must strive for objectivity, ensuring that their decisions reflect the collective views of society, and second, that they exercise restraint, upholding the Constitution but not intruding upon the preserve of the legislature and executive branches of government. Madame Justice McLachlin then examines the issue of remedies under the Charter; focusing on how the courts should enforce the rights and freedoms which the Charter has guaranteed. The answer, she suggests, must be found in respect, tradition and constitutional convention focusing on politicaljudicial cooperation.
Dans le texte de sa conférence «Weir Memorial Lecture», Mme le juge McLachlin relève les changements fondamentaux que l'adoption de la Charte canadienne des droits et libertés a apportés dans le rôle des tribunaux canadiens, et elle aborde la facon dont ils devraient assumer les nouvelles responsabilités que leur confère la Charte. Mme le juge McLachlin examine en premier lieu la gamme de questions sociales et morales qui n'étaient auparavant pas du ressort des tribunaux. les difficultés que posent les prises de décision judiciaires en l'absence de jurisprudence. le langage ouvert de la Charte et la nécessité de prononcer des jugements fondés sur des valeurs. Madame le juge McLachlin suggere que les tribunaux doivent en premier lieu viser l'objectivité et s'assurer que les arrêts reflètent les vues collectives de la société; ils doivent ensuite s'imposer des limites et respecter la Constitution sans empiéter sur les pouvoirs législatifs et exécutifs du gouvernement. Mme le juge McLachlin examine ensuite la question des recours invoquant la Charte et décrit comment les tribunaux devraient faire respecter les droits et libertés qu' elle garantit, la réponse se trouvant dans le respect des traditions et de la convention constitutionnelle axée sur la coopération entre le politique et le judiciaire.

\section{TABLE OF CONTENTS}

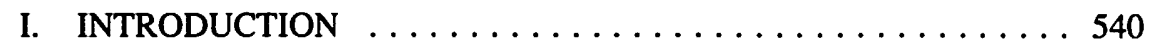

II. DECISION-MAKING UNDER THE CHARTER . . . . . . . . 542

III. REMEDIES UNDER THE CHARTER $\ldots \ldots \ldots \ldots \ldots \ldots \ldots .548$

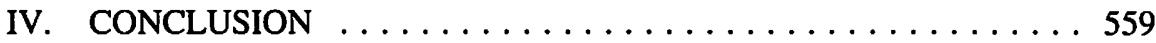

\section{INTRODUCTION}

Eight years ago, Canada adopted the Canadian Charter of Rights and Freedoms. It was a change breathtaking in scope, so large that one wonders, in retrospect, how it was accomplished. Since Confederation, Canada had followed the British model. Individual rights and freedoms were important. But their preservation was a matter of tradition and the will of the Legislature. The Charter entrenched individual rights and freedoms in our Constitution, and in doing so, turned the tables of power. Before the Charter, Parliament and the Legislatures were free to limit individual rights and freedoms as they thought fit, 
subject only to the check of tradition and public opinion, and the basic requirement that the legislation was within an area of competence under the British North America Act. The Charter took away that freedom. It became the supreme guarantee of individual rights and freedoms. Parliament and the Legislatures were powerless to limit those rights and freedoms except in accordance with its terms. We had changed from a British system, in which the Crown, acting through the legislative and executive branches, was supreme, to a system more akin to that of the United States, where the law itself was supreme. And since the courts are the ultimate arbiters of that law, the courts assumed a newly important role as the institution which determines what can and cannot be the law.

This new role for the judiciary was predicted and predictable. One had only to look at the American experience to forecast its inevitability. When the American Bill of Rights was adopted, it was sanguinely predicted that the judiciary is "the least dangerous branch of government." 1 One has only to recall the leading role which the U.S. Supreme Court played in the fight for legal equality and desegregation in the 60's to see the gross miscalculation of that assessment. The Bill of Rights has made the United States Supreme Court an instrument of great and critical power. The Charter can lead only in the same direction if, as I shall suggest, with a different outcome.

It is not my intention to debate whether this development is good or bad. I recognize that that debate continues. Only a month or so ago, a law professor in a leading Canadian newspaper ${ }^{2}$ bewailed the fact that "the judges have used the Charter of Rights and Freedoms to make themselves the final arbiter of what is right and just. They have proclaimed themselves the "guardians of the constitution'." The fact is that the Constitution, not the judges, compels the courts to act as final arbiters of what is right and just, to stand as the guardians of the Constitution. While the courts may choose between relative degrees of judicial activism, and while the extent to which they defer to the legislative branch may vary, the fundamental fact remains that the courts cannot avoid the new responsibilities and powers which the Charter has placed upon them. The question is not whether they do it, but how they do it.

It is the latter question which I wish to address. How should the courts go about discharging the new responsibilities which the Charter has placed upon them? What implications does the Charter hold for judicial decision-making and judicial remedies? What role does this mandate for judges, and how will the judiciary in the twenty-first century relate to the legislative and executive branches of government?

I sub-divide the central question of how the courts should discharge their responsibilities under the Charter into two headings: decision-making and remedies. The nature of the Charter is such that it requires judges to address new problems and issues in decision-making. And its impact is such that it requires the courts to consider anew

\footnotetext{
A. Hamilton, The Federalist Papers (1788), No. 78

R. Martin, "Choosing our judges: Judges should be told their task is simply to decide legal cases" The [Ottawa] Citizen (10 Sep. 1990) A 9.
} 
what remedies should be granted where breaches of the Charter occur. I will consider each of these issues in turn.

\section{DECISION-MAKING UNDER THE CHARTER}

I turn first to the issue of decision-making under the Charter. Under this head I propose to discuss the vastly expanded range of subject matter which is being brought before the courts as a consequence of the Charter, as well as the actual decision-making process under the Charter.

The first thing that judges must adjust to in the post-Charter world is the fact that suddenly they are expected to render decisions on matters which they could not have imagined in their law school days. The Charter's guarantees of rights and freedoms has made litigable a vast range of questions which previously would have been beyond the powers of the courts.

Prior to the Charter, the main business of the courts was maintaining the criminal justice system and resolving private disputes. Contract, tort and criminal law, with a smattering of the esoteric by way of trusts or admiralty - these were the staples of the law. Most people passed their lives without going near the courts or perceiving themselves as affected by them in any way. Today's decision at the Supreme Court of Canada was hardly likely to excite debate at the family dinner table, to say the least.

The Charter has changed all that. It has done so by the simple mechanism of saying that laws and government action may not impinge on the fundamental rights and freedoms guaranteed by the Charter. Given the wide scope of legislation and government action in the waning years of the twentieth century, the result is inevitable. A whole range of questions touching everyday life which were formerly matters exclusively for the legislators are now fodder for the courts - Sunday shopping, abortion, mandatory retirement and hate propaganda - to name but a few issues which have captured recent headlines.

The result has been that judges, particularly at the appellate level, find themselves facing questions which are new and unfamiliar. Many involve social and moral values, foreign territory to a judge raised on the arid objectivity of contracts and bills of lading. It is not enough to demand, as one writer recently did, that our judges "stop trying to be our moral mentors and get back to deciding cases". ${ }^{3}$ As I have already suggested, the proposed distinction between "deciding cases" and engaging in evaluative moral questions is a false dichotomy. There is no way to interpret the Charter without making value judgments. The abortion issue which has twice come before our Court provides a graphic example. The courts had no choice but to deal with the issues of criminal law raised by the Morgentaler ${ }^{4}$ case or the central issue of personal freedom raised in the Daigle matters. And faced with those issues, they had no choice but to make what some would

Ibid.

R. v. Morgentaler, [1988] I S.C.R. 30, 44 D.L.R. (4th) 385.

Tremblay v. Daigle. [1989] 2 S.C.R 530. 62 D.L.R. (4th) 634. 
label moral judgments. To reject Chantal Daigle's right to an abortion (as did the Quebec Court of Appeal), was as much a moral judgment as to accept it (as did the Supreme Court). The courts can decline to take on questions which are not squarely raised or premature, as did the Supreme Court in the Borowski ${ }^{6}$ case. But often there is no choice but to struggle with the new and difficult issue. The bottom line is clear - the Charter's introduction of guarantees for individual rights and freedoms means that the courts have no choice but to grapple with a whole range of hitherto unlitigable issues, many of them involving social and moral questions of profound importance and difficulty.

How can we ensure that our courts can best discharge this new task? It is obvious that they must remain in touch with the world about them if they are to render relevant and helpful decisions. It is also obvious that the composition of the courts should reflect insofar as possible the broad mosaic of our society, the better to guard against the predominance of uniform insularity. That judges must be objective, independent and sensitive to prevailing social thought and concern is beyond dispute. Only thus can our courts cope with the wave of new issues which the Charter has washed up on their benches.

Quite apart from the increase in the range of litigable issues which it has introduced, the Charter has profoundly affected the task of judicial decision making. Three factors contribute to the difficulty judges encounter in making decisions under the Charter: first, the absence of precedent; second, the open-textured language of the Charter; and third, the necessity of making value-based decisions. I will comment briefly on each of these factors.

To understand the significance of the absence of precedent, it is necessary to contrast the method of judicial decision-making in the common law provinces apart from the Charter, with the method which prevails under the Charter. The art of the common law lawyer - the essence of what he or she learns at law school - is the art of applying precedent. The common law developed incrementally, on a case by case basis. Rules of general application were regarded with suspicion. It was thought safer and better that the law advance by doing what had been done in a previous case, subject to such modification as the distinct facts of the case at bar might demand. Lawyers argue their cases and judges decide them by this method. Even where legislation is involved, previous cases interpreting it hold great importance.

Consider then the sinking feeling that besets a common law lawyer upon finding himself or herself confronted by a new document, an amalgam of unfamiliar American and European and who-knows-what-other ideas, without so much as a case to show the way. That is the problem which the Charter posed for the judiciary. Where, we asked, do we go for the answers? Do we look south of the border? Surely that cannot be the answer, given the uniqueness of our country and the Charter. Do we look to the Canadian Bill of Rights? But that was a totally different document, and not constitutionally entrenched. 
Over the past eight years, the courts have been developing precedents on the Charter. A trial judge makes a decision. Courts of Appeal ponder it and elaborate. Ultimately, it comes to the Supreme Court of Canada, which lays down the definitive answer, which courts below can then apply.

That is the theory, and in large part it has worked. We now have an emerging doctrine on free speech, pre-trial liberties, equality rights and the methods to balance the state's interest in legislation limiting rights against the right of the individual under $\mathrm{s} .1$ of the Charter. The Supreme Court has struggled to give guidance by laying down general principles, while leaving open questions better resolved in the future. The question of how far to go in formulating a legal structure is always one of difficulty and delicacy. Sometimes, moreover, it is necessary to take a step back and reconsider previous decisions. But by and large the process continues to infuse at least some direction, some small measure of guidance, for future cases.

But the process is not as simple as building up rules and cases which can be mechanically applied. If that were the case, we could envisage a day when the Charter jurisprudence was "complete", all vagaries resolved, all lacunae filled. That will never happen, because, as we are increasingly coming to realize, the Charter is not a document like other laws, to which common law precedent can be applied with little difficulty. The Charter by nature is more akin to the Napoleonic Code or the Quebec Civil Code, where precedent is at best of limited value. It sets out general principles which constitute the ultimate law. It is these principles, not the cases which interpret them, which are supreme. The cases must always be essentially secondary. The result is that, as new situations emerge, the courts will inevitably disregard precedent to interpret the Charter in a way which conforms to the prevailing perception of right and wrong. It is for this reason that the Supreme Court of Canada has repeatedly stated that the Charter must not be viewed as a static document, frozen in time by this decision or that. ${ }^{7}$ Any doubt on that matter is resolved by a look at the American experience. In the 19th century the Bill of Rights was interpreted as upholding slavery; in the twentieth, it became a powerful engine for racial equality and desegregation. The Bill of Rights did not change. The old cases remained on the books. What changed was society, and with it the courts' interpretation of what the Constitution meant.

These considerations highlight another reason why precedent cannot operate in the context of the Charter as it does in other areas of the law. On non-constitutional questions, Parliament and the Legislatures can pass laws changing the rules which judges make. Judges can follow previous decisions in the confidence that if they were not sound, laws would have been passed to change them. This is not true of constitutional decisions, however. If the courts say that a certain law is unconstitutional, Parliament and the Legislatures must abide by that decision. They cannot change it. It follows that the only means of changing or rectifying constitutional decisions is the courts themselves. Slavish adherence to precedent by the courts would mean that errors or aberrations in 
constitutional interpretation could never be corrected. For this reason, the highest constitutional courts must be prepared on occasion - hopefully not too often in the interests of certainty in the law - to reconsider their constitutional decisions. The highest courts in Britain, Australia, the United States and Canada now assert the power to reverse earlier decisions which prove inappropriate, as witness the recent reversal by the Supreme Court of Canada in the sexual discrimination cases. ${ }^{8}$

The result is clear. The absence of precedent is not a temporary void which will be remedied in due course when the courts have pronounced enough decisions. Court decisions will help in establishing parameters and providing guidance in the vast majority of cases. But the Charter by its very nature defies the possibility of absolute and permanent interpretational certainty. Judges in 2050 will be searching the Charter for the correct answers for the society of their day, just as we do for our society. Viewed thus, the Charter poses a continuing and permanent challenge for the judge accustomed to looking to precedent for the answers.

I turn next to the challenges posed by the language of the Charter. The language of the Charter is extremely open-textured. The guarantees of rights and freedoms are cast in broad terms - the right to vote, freedom of expression, freedom of association, freedom of religion, the right to life, liberty and security of person, the right to equality and so on. The words hold meaning for all of us, but when we examine that meaning, we find that it is far from precise. When we recite a phrase like "freedom of expression" certain ideas come to mind - a free press, the right of political expression, perhaps artistic expression. But while the core of these concepts may be solid, the penumbra is vague and indefinite. Should the right of free expression, for example, extend to pornography? To hate propaganda? Similarly with the democratic rights. Does the right to vote comport a certain equality of voting power? If perfect equality is impossible, what degree of equality is required to fulfil the constitutional guarantee? Equally difficult, what is meant by the notion of equality? Equal opportunity? The right of persons similarly situated to be similarly treated? Or a more restrictive notion tied to the concept of discrimination and groups which have traditionally been discriminated against?

It is readily apparent that questions such as these are susceptible to a variety of different answers. It falls to the courts to provide the answers. Where are they to find them?

A final and related challenge to judges lies in the impossibility of avoiding value judgments in Charter decision-making. Value judgments are inherent in defining the scope of the rights and freedoms guaranteed by the Charter. To say, for example, that free speech extends to a particular form of expression, is to make a value judgment $-\mathbf{a}$ judgment that that form of expression should receive Charter protection. But the necessity of making value judgments is clearest under s. 1 of the Charter, where courts are required to determine whether a law which limits a right or freedom guaranteed by 
the Charter is nevertheless "demonstrably justified" as a "reasonable limit" in a "free and democratic society."

The peculiarity of value judgments is that while they may seem rational, they are essentially arbitrary, in the sense that they cannot be proven true or false in the way statements of fact can. Reasonable people can differ on what is good, as the Socratic debates made clear so many thousand years ago, and there is no clear way of demonstrating that one view is right and the other view wrong. Thus, reasonable people may differ on what expression is protected by the Charter or what constitutes unacceptable social inequality.

Traditionally, these difficult value judgments have been made by our legislators on the basis of the values of the constituencies they represent. But now, under the Charter, judges are required to address them.

There can be only two sources of solutions to the problem of defining the uncertain penumbra of Charter rights and addressing the problem of making value judgments. First, judges may look into themselves and base their answers on their own values and instincts. Alternatively, judges can attempt to look outside themselves, basing their judgments on the norms and values they see reflected in society at large.

There can be no doubt that the decisions of judges reflect to some extent their personal values. Nevertheless, the importance of personal beliefs and opinions in judicial decisionmaking is often over-stated. We frequently hear calls for fuller examination of the personal views of prospective judges. We should have a public process, we are told, where the views of judicial candidates can be explored. The American experience with Senatorial hearings for judicial candidates suggests that such hearings will reveal little of the candidate's beliefs on controversial issues; the standard and correct response to such inquiries is that which Sandra Day O'Connor gave at her confirmation hearings to the question of her views on abortion: I cannot answer because that is a question which may well come before the Court, at which time I shall decide it in accordance with the submissions and evidence placed before me. Sueter, recently confirmed, took the same approach. Do you want, he asked his questioners, a judge who is unprepared to consider arguments, who is governed by inflexible opinion?

But even if such hearings did reveal personal views, it is doubtful how much relevance they would have. The cry for more intensive examination of judges' personal beliefs confuses the judge's private views with the professional discharge of his or her duties. Judges are human. As humans, they cannot but have opinions, sometimes prejudices. But it is their duty to set aside their personal prejudices and views when they make judicial decisions and to found those decisions on an impartial assessment of the evidence and legal authority. And after almost a decade in the judicial business, I can attest to the fact that most judges do this. In the result, a judge's temperament, and in particular his or her ability to set to one side preconceived views and look at the question in dispute objectively, is much more important than any personal views the judge may hold on the subject. What is required of our judges in the post-Charter era, above all, is what has been called the quality of "active humility", which enables the judge to set aside 
preconceptions and prejudices and look at the question afresh in the light of the evidence and counsel's submissions. ${ }^{9}$

I thus reject the first alternative - that judges find the values required for Charter interpretation in their own personal beliefs. This leaves the alternative that judges find the answers to the difficult questions posed by the open-textured language of the Charter in sources outside themselves. But how are they to do this? I have already suggested that they must look to the evidence and argumentation in the case before them. But that does not answer the question of how they are to choose between conflicting submissions.

The best solution, it seems to me, lies in seeking the dominant views being expressed in society at large on the question in issue. What has been written and said on the point in question? What values are inherent in what has been written and said? Often conflicting views are presented. The judge must then examine the values on which the conflict arises and decide which is most in keeping with the purposes of the Charter guarantee in question. The reference to external values will ensure that the judge does not decide on the basis of his or her prejudices, while the emphasis on the purposes of the Charter ensures that the judge will not stray too far from the essence of the guarantee in question. The result will be an objective, responsible approach to constitutional decision-making.

Occasionally decisions under the Charter, particularly s. 1 , involve judges in decisions which may be characterized as political or economic. The consequences of striking down a mandatory retirement law on grounds that it constitutes unequal treatment of the elderly, for example, may have far-reaching economic consequences. No one can dispute that the desegregation decisions in the United States had vast economic repercussions. While the equality provisions of s. 15 remain to be explored, judgments requiring hiring of "quotas" of minority groups or providing "equal" services and opportunities to disadvantaged groups might similarly have significant economic consequences.

Traditionally, the spending power has been tied to the representation function in our democracy. No taxation without representation is a fundamental precept of western political theory. Our legislators, when they pass laws, may be presumed to have considered the costs involved. Should the courts be permitted to change the economic equation by striking out laws or introducing new requirements?

The easy answer is that all law-making is subject to the Constitution, and hence that the courts are merely correcting the economic choices of the Legislatures to conform with the Constitution. Yet judicial forays into economic issues continue to provoke a certain unease. My own view is that the courts should show great deference to legislative determinations of where and how public money should be spent. Only where it is clear that the law or policy in question cannot be sustained as reasonable under $\mathrm{s} .1$ of the Charter should they step in, and then only to the extent actually required to correct the

9. J. Webber, "Choosing our judges: Canada's courts need diversity, openness" The [Ottawa] Citizen (Sep. 5, 1990) A 11. 
violation in question. The nature of $s .1$ is such that where governments act reasonably, in furtherance of legitimate goals, and without overreaching, their laws will withstand Charter scrutiny. On the other hand, the limited intrusion of the courts into economic areas is justifiable where Legislatures act for illegitimate reasons or overreach by introducing unnecessarily broad legislation. The Charter is the supreme law of the land, and its values must be upheld, notwithstanding the economic consequences.

To summarize, judicial decision-making under the Charter must be flexible and responsive. Our courts must be capable of addressing a plethora of social and moral problems which only a short decade ago were non-litigable. And in addressing those problems, they must meet certain difficulties inherent in Charter decision-making - the absence of precedent to act as a guide; the open-textured language of the Charter; and the need to make value judgments - occasionally of a political and economic nature - which would once have been considered the exclusive domain of Parliament and the Legislatures. In addressing the problems presented by the Charter, the courts must strive for objectivity; their decisions should reflect not their personal views so much as the collective views of society. And while remaining true to their duty to uphold the Constitution, they must exercise restraint, preserving to the legislative and executive branches of government their proper sphere within the bounds of the Constitution.

\section{REMEDIES UNDER THE CHARTER}

I turn now to the second way in which the Charter has impacted on the functioning of the courts - the problem of remedies. While less glamorous than the substantive law, remedies are of fundamental importance. As Lord Denning has put it: ${ }^{10}$

The only admissible remedy for any abuse of power - in a civilized society - is by recourse to law. In order to ensure this recourse, it is important the law itself should provide adequate and efficient remedies for the abuse of or misuse of power from whatever quarter it may come.

Without effective remedies, the law becomes an empty symbol; full of sound and fury but signifying nothing. One need only look to the elaborate guarantees of rights found in the constitutions of many non-democratic counties for evidence of the importance of effective remedies. The paper reads magnificently, but the reality is otherwise.

The pre-Charter law recognized certain grievances and provided certain remedies for them - damages, declarations, injunctions, fines and imprisonment. The Charter, by entrenching individual rights and freedoms, has created a broad new range of legal grievances. The question, quite simply, is what the remedies for these new legal rights should be. More particularly, how are the courts to enforce the rights and freedoms which are each citizen's constitutional right?

The problem reflects a basic shift in the relationship between the courts and the government effected by the Charter. On the traditional British theory of the state, to 
which Canada adhered until it adopted the Charter, the Crown was supreme, and the courts, although independent, acted as its emanation. Enforcement of court orders in these circumstances was generally not a problem. The Charter changes that equation. The contest is typically between the individual and the state. The Court is the independent arbiter. When the Court says that the state has infringed the individual's rights, what power has it to ensure that the state remedies the situation? How is the Court to secure compliance with its edicts in the post-Charter era? The answer must be found in respect, tradition and constitutional convention. As Strayer J. has put it: ${ }^{11}$

[T] he courts must command the respect, or at least maintain the acquiescence, of other branches and levels of Government, and of the public, to be effective. They have no armies or police forces to enforce their will in constitutional matters.

The problem of enforcement is inextricably tied up with the problem of how much change and what kind of change is wise. This question arises, for example, when the Court is confronted with the need to strike out unconstitutional legislation. Section 52 of the Charter says that legislation is of no force and effect to the extent that it infringes the Charter. But sometimes striking down legislation may be inappropriate, as where the result would leave a constitutional or legislative vacuum pending rectification of the problem. Again, striking the legislation out may be insufficient, may even defeat the purpose of the Charter right in question. The question then arises of whether the Court should prolong the legislation pending amendment, or whether the Court should fashion remedies requiring corrective government action. In extreme cases, it may be suggested that the courts themselves should take a supervisory role in the enforcement of the remedy they prescribe.

It is my submission that we have in Canada the beginnings of a constitutional convention which may in large part resolve the difficult interface between the judiciary and other government bodies. Before elaborating on this emerging model, however, it is not amiss to take a brief view of matters south of the border where relations between the judiciary and the legislative and executive branches of government - and, indeed, between different levels of the judiciary - have often been marred by problems of enforcement of constitutional rulings.

The first hurdle encountered by American Judges was the question of whether or not it was appropriate to engage in judicial review at all. Unlike the Canadian Constitution, the American Constitution has no equivalent to s. 52 and does not explicitly provide that laws which contravene the Constitution could be declared invalid. In fact, the authority to determine the meaning or application of the Constitution is not mentioned anywhere in the document itself. ${ }^{12}$ The issue of whether or not courts could strike legislation as contravening the Constitution was faced head on in Marbury v. Madison. ${ }^{13}$ The Plaintiff

II. B.L. Strayer, The Canadian Constitution and the Courts, 3rd ed. (Toronto: Butterworths, 1988) at 340.

12. A. M. Bickel, The Least Dangerous Branch, 2nd ed. (New Haven: Yale University Press, 1986) at 1.

13. (1803), 1 Cranch 137, 2 L.Ed. 60. 
in Marbury was appointed a Justice of the Peace at the end of President Adams' term in office but the appointment did not materialize. Marbury then brought an action against Secretary Madison for the delivery of his commission. Justice Marshall for the Supreme Court held that Marbury was entitled to the commission but that the Court had no power to order Madison to deliver it because the relevant section of the Judiciary Act contravened the Constitution. After reviewing several clauses in the Constitution, the Court concluded that "the particular phraseology of the Constitution of the United States confirms and strengthens the principle supposed to be essential to all written constitutions, that a law repugnant to the constitution is void" and that it is for the federal courts to declare it so. ${ }^{14}$ Initial reaction to Marbury included public outrage and rumours that Chief Justice Marshall would be impeached if he continued declaring congressional acts unconstitutional. ${ }^{\text {15 }}$

It has been almost 200 years since Marbury and today few would question that the Court has the power to engage in some types of judicial review. Nevertheless, Marbury initiated a debate which continues to this day on the scope of the power to review. As the Court began taking on an activist approach, particularly when the Court attempted to fashion remedies in civil rights cases, it met resistance and sometimes open defiance from lower courts, the bureaucracy and the executive.

I turn first to defiance by lower courts. While defiance may occasionally be politically wise for elected judges in the United States, even appointed federal court judges occasionally responded to local pressures by avoiding or defying Supreme Court decisions. Reaction to the school segregation case, Brown v. Board of Education ${ }^{16}$ is cited by many writers as a classic example of such defiance. In Brown the Court held that segregation in public schools violated the fourteenth amendment. School Boards were directed to rectify the situation with "all deliberate speed." The school board's performance was to be supervised by lower federal courts. If school boards did not comply, black citizens could bring an action in the federal district courts to challenge continued segregation. Under the terms of the judgment, federal courts were to have discretion to create remedies that took local conditions into account. By leaving the terms of enforcement in broad terms, the Supreme Court unintentionally allowed room for lower court judges to evade the judgment. ${ }^{17}$ Many judges disagreed with the Brown decision and others felt local pressures not to comply. ${ }^{18}$ This phenomenon is explained by one writer as follows: ${ }^{19}$

Federal judges, who are appointed for life, might seem to be immune from these political concems. But they too may wish to avoid incurring public wrath. Full adherence to Brown v. Board of Education would have made district judges's lives less pleasant because of the reactions of their friends and neighbours. J. Skelly Wright of Louisiana, who did adhere to Brown, found that his life was affected a

As summarized in The Least Dangerous Branch, supra, note 12 at 12.

G. McDowell, Curbing the Courts (Louisiana: Louisiana State University Press, 1988) at 136. (1954), 347 U.S. 483, (1955), 349 U.S. 294.

J. Grossman, Constitutional Law and Judicial Policy Making, 3rd ed. (New York: Longman Inc. 1988) at 19.

L. Baum, The Supreme Court, 3rd ed. (Washington: Congressional Quarterly Press, 1989) at 206. Ibid. at 217. 
great deal, "You never know whether people really want to talk with you and I don't see a lot of people any more." Wright also had to endure public attacks, which included a demonstration in which parents and children from integrated New Orleans schools brought an effigy of him in a coffin into the state capitol to the applause of legislators...

These judges were willing to accept the costs of supporting the Supreme Court, and northern federal judges such as W. Arthur Garrity in Boston have ordered school desegregation despite the prospect of severe public criticism. But these are exceptions to the general pattern. Where the perceived impact of carrying out a decision is highly negative, most people will offer less than total support to the Court..

In the result, many judges gave in to local pressures and it took several years and subsequent cases before the segregation issues were resolved. One cannot but conclude that judicial non-compliance has significantly hampered the United States Supreme Court's effectiveness.

The Supreme Court's effectiveness has also been hampered by non-compliance of the bureaucracy. Many Supreme Court decisions require implementation by members of the bureaucracy. As was the case with some lower court judges, examples abound of cases where implementation of court decisions has been hampered by uncooperative behaviour within the bureaucracies charged with carrying out the terms of the decision. An example of such behaviour is evidenced in actions taken after the Supreme Court's decision in Goldberg v. Kelly. ${ }^{20}$ In Goldberg the Court held that welfare recipients were entitled to due process rights before their welfare benefits could be terminated. However, one study of the New York welfare agency revealed that in the year following the decision 5 per cent of the appellants received no prior notice that welfare benefits were going to be terminated, 25 per cent did not receive timely notice, two-thirds of the notices failed to clearly state the action proposed and reasons for it, etc. ${ }^{21}$

If the bureaucracy does not comply with edicts of the Court then affected citizens are forced to bring further cases in order to have their rights protected. As a consequence, non-compliance produces additional expense for the citizens whose rights are supposed to be protected by the Constitution and results in the deprivation of rights to the vast majority who are unwilling or unable to fight for them.

I turn finally to the response of Congress, the Senate and the State Legislatures to controversial Supreme Court decisions. Here, the pattern is one of criticism and inadvertence rather than open defiance. Reactions have included legitimate means of control (such as relying on constitutional amendment), as well as indirect means of control.

Congress, faced with a court decision which it cannot overturn directly through statute, may respond by enacting narrowly amended statutes intended to comply with the letter rather than the substance of the law. Where this will not work, Congress in some

21. D. Kirchheimer, "Community Evaluation of Fair Hearing Procedures Available to Public Assistance Recipients," May, 1973, cited in Grossman, supra, note 17 at 22. 
situations has reverted to constitutional amendment. Such devices have been used on at least five occasions to nullify the effect of court decisions. ${ }^{22}$ However, constitutional amendments are not always easy to achieve, and as a consequence a number of less honourable methods have from time to time been resorted to in an attempt to control judicial intervention.

As noted earlier, when Chief Justice Marshall first held that the Court could strike legislation which contravened the Constitution, rumours of his threatened impeachment quickly arose. Similar attempts to oust the power of the judiciary have surfaced periodically throughout American judicial history. Judges have also frequently found themselves the object of verbal attacks by members of Congress. For example, one congressman unhappy with a decision on state regulation of subversive activities, stated that the Court was "a greater threat to this Union than the entire confines of Soviet Russia. If some way is not found to stop them, God help us. ${ }^{23}$ Congress has also used its power over the Court's jurisdiction by changing the scope of its mandate; for example, revoking its right to hear appeals in habeas corpus actions. ${ }^{24}$ Through its control over the budget, Congress can have a major impact over how or if decisions are complied with by providing or failing to provide funds to carry out a decision. ${ }^{25}$ Control may be attempted through tampering with judicial salaries. The Court's civil liberties policies and Congress's dissatisfaction with them may explain why in 1964 the Supreme Court justice salaries were increased by $\$ 3,000$ less than raises given to other federal judges. ${ }^{26}$ Finally, Presidents have reacted negatively to the perceived strength of the Court. For example, some attempted to change court policies by adding members to the Court - the famous Roosevelt court-packing gambit. ${ }^{27}$

Sometimes tactics such as those which I have described have enjoyed limited success. In the long run, however, they have not significantly undermined the power of the United States Supreme Court, nor prevented the Supreme Court from taking an activist stance where it felt the issue required it. In the end, as we all know, the Court did declare racial segregation to be wrong, and its decisions were by and large enforced. Nevertheless, the process proved to be long and tension-fraught. Disillusionment followed when the inevitable evasions occurred and segregation continued. Some judges refused to act; others fought back, responding by giving detailed, literal orders, virtually taking over the administration of schools or dictating the development of desegregated housing. The result was judge as administrator. The image of a judge making day to day operational

22. The eleventh amendment overturned Chisolm v. Georgia (1793). The fourteenth amendment nullified part of the Dred Scott decision (1857). The sixteenth reversed Pollock v. Farmers' Loan and Trust Co. (1895). The twenty-sixth amendment nullified Oregan v. Mitchell (1970).: Baum, supra, note 18 at 226.

U.S. Congress, House, Congressional Record, 84th Cong., 2d sess., 1956, 102, Pt. 5:6385, cited in Baum, supra, at 227.

In 1869 Congress withdrew the Court's right to hear appeals in habeas corpus actions in order to prevent it from deciding a challenge to the Post-Civil War Reconstruction legislation. See Baum. supra, at 227.

Baum, supra, at 229.

Ibid. at 228.

Ibid. 
decisions in the running of a school - down to what kind of tennis balls to order in one case - is hardly one most Canadian judges would embrace. ${ }^{28}$

The verdict on the results of judicial administration, is, to put it at its highest, mixed, suggesting it is not an alternative lightly to be embraced in this country. Practical problems rise out of the courts inability to administer that which it has prescribed. ${ }^{29}$ Constitutional separation of powers problems are posed by judicial interference with state appropriation of funds. ${ }^{30}$ For example, the landmark mental health care decision in Wyatt v. Stickney ${ }^{31}$ led to a quadrupling of Alabama's spending on mental institutions in the year following the decision. ${ }^{32}$ Also at risk is the impartiality and neutrality of the judiciary, perceived and actual. Judicial management almost inevitably leads to conflict with the bureaucracy, whose decisions have been overruled by the Court, thus placing judges in an adversarial relationship with one of the parties before the Court. ${ }^{33}$ Still, despite all the problems, all the delays, and all the evasions, the Court's pronouncement in Brown v. Board of Education in the end won the day and more and more legislators and administrators accepted the need to bring their institutions into conformity with the precepts laid down by the Court.

In summary, American courts have faced considerable difficulty in enforcing their rulings under the Constitution - difficulties provoked by the obduracy of lower courts, the bureaucracy and even the Legislatures. While the courts have prevailed in the end, it has been at the cost of delay, frustration and additional cost, not to mention strained relationships between lower court judiciary and Supreme Court judiciary and occasional open hostility between the legislative and judicial branches.

The question is whether in Canada we can avoid these pitfalls. It is my view that we can. We have in Canada the beginnings of a tradition of cooperation instead of conflict, which, if we can follow it, promises a more harmonious relationship between the judiciary and other branches of government than that which has historically prevailed in the United States.

There being a long tradition in the Anglo-Canadian law of the courts refusing to make an order or enforce a contract "the execution whereof would require continued superintendence by the court" as was noted in I.C.F. Spry, The Principles of Equitable Remedies: Injunctions, Specific Performance and Equitable Damages (London: Sweet \& Maxwell, 1981) at 95.

29. These being concerns that have traditionally led Canadian judges to avoid involvement in such questions. See M. Valpy, "New Jersey's Folly Can Teach Us a Lesson" The Globe and Mail (Sep. $25,1989)$ A 8 for a discussion of the damage caused by judicial interference with residential zoning in New Jersey.

30. Courts are generally reluctant to interfere with allocative decisions of the state. Many decisions have held that where the legislature fails to make an appropriation, a court is powerless to remedy any resulting inequities. See Myers v. English (1858), 9 Cal. 341, and "The Califomia Supreme Court Survey: California Constitutional Law, Doctrine of Separation of Powers" (1982) 9 Pepperdine Law Review 677, at 715.

31. (1971) 235 F. Supp. 781 (M.D.Ala.).

32. See D.L. Horowitz, "Decreeing Organizational Change: Judicial Supervision of Public Institutions" [1983] Duke Law Journal 1265 at 1267.

33. Ibid. at 1303-304. This change also suggests that judicial decisions must be evaluated for "effectiveness" as well as "rightness". 
Before turning to the evidence of that emerging tradition, I would like to comment on some of the factors which make it possible. The first point is that judicial intervention may possess a legitimacy in Canada which was not apparent in the early years of American constitutional development. Unlike the American Constitution, the Canadian Constitution expressly provides that legislation which contravenes Charter rights is invalid: s. 52. While judicial action in the United States may be undermined by the presumption that the judiciary cannot legitimately intervene, this cannot be said in Canada. Judicial review is undoubtedly a legitimate function of Canadian courts.

Nor does the Charter stop with giving the courts the power to strike offending legislation. Section 24(1) of the Charter allows courts to award "such remedy as the court considers appropriate and just in the circumstances." Thus it is arguable that the Supreme Court may be as innovative as is necessary to fashion an appropriate and just remedy. ${ }^{34}$ The legitimacy of court intervention is further evidenced by the wording of certain of the rights in the Charter which provide that rights may be infringed, not only by government action, but also by inaction. ${ }^{35}$ This may be perceived as an invitation to the courts to prescribe legislative action. For example, s. 23 imposes on the provinces a constitutional duty to provide minority language instruction. If a province fails to do so, the Court may require it to take action to effect compliance with the section: Mahe v. The Province of Alberta. ${ }^{36}$

Judicial intervention may also be seen as more legitimate in Canada since it was Parliament and the Legislatures themselves which granted the Court its powers by virtue of ss. 52, 24(1) and some of the rights provisions. Unlike the situation in the United States where the courts "took" the power, Canadian courts were granted the power by the Legislatures. Legislatures in Canada can hardly profess to be surprised when courts perform the very functions which they themselves have conferred on them.

Finally, unlike the American situation, Canadian Legislatures retain ultimate control over most issues by virtue of the override provision. Section 33 of the Charter gives the Legislatures the right to override the Court's rulings on all but a few Charter rights, subject to the condition that overriding legislation be reviewed within five years. While it may be politically difficult for Legislatures to rely on the override provision, the fact remains that it provides protection if it is perceived that the Court has stepped out of line. Thus, judicial intervention in Canada may not be seen by Legislatures as threatening their supremacy in the same way that has occurred in the United States.

The second point is that the political/judicial climate in Canada - the way the legislative and judicial branches view each other - may be different in Canada than in the United States. While the American model reveals a pattern of conflict and a tug-of-war battle for control between the legislative, executive and judicial branches, Canadian history reveals a tradition of judicial restraint and judicial/legislative co-operation.

D. Gibson, The Law of the Charter (Toronto: Carswell, 1986) at 198.

D. Réaume \& L. Green, "Education and Linguistic Security in the Charter" (1989) 34 McGill L.J. 778 at 811.

(1987), 80 A.R. 161, 42 D.L.R. (4th) 514 'Alta.C.A.). 
The reasons for this different tradition are varied. First, the different political climate may help to alleviate criticism and problems encountered by Legislatures and executive branches. Although Supreme Court judges in Canada are appointed by politicians, the appointments are not made in the overtly political fashion that Supreme Court judges in the United States are. Because U.S. appointments require approval of Congress, a new appointment may be disliked by the opposition party even before he or she has rendered any decisions. Moreover, the openly political nature of many judicial appointments in the United States may pit a subsequent government against a judiciary that espouses a different belief system. Canadian Supreme Court judges are not openly identified with a political party. As a result, a change in government in Canada does not create the same tensions that arise in the United States.

Second, Canadian judges have traditionally exercised judicial restraint and normally answer only the question directly before them. Broad sweeping directives have not been part of our judicial history. This is not likely to change because of the enactment of the Charter. Commonwealth judges, by training and temperament, are most comfortable with the traditional judicial role of applying established precedents and the laws made by others to familiar situations. Our courts, while responding to similar pressures when faced with a new role under the Charter, nevertheless remain concerned not to trench too much on the legislative role. Moreover, our judges are acutely aware of the dangers and difficulties inherent in the new role that, whether they like it or not, is being thrust upon them. Because of this attitude of restraint, the tug-of-war atmosphere that exists in the United States is not as likely to arise in Canada. Historically, although the Supreme Court of Canada has taken a more activist stance when it has been necessary to do so (for example, during the 1950's in the Duplessis reign the Court rendered several decisions which were of a more activist nature), it has generally refrained from activism where it was not necessary to do so. In interpreting constitutional decisions on division of power issues, for example, the Court has traditionally been concerned with constitutional validity, rather than the merits of the particular government action or legislation in question.

The Supreme Court under the Charter has undoubtedly assumed a more activist role. Nevertheless, the attitude of judicial restraint and respect for Parliament and the Legislatures remains, surfacing particularly in more recent decisions. As Chief Justice Dickson reaffirmed in $R$. v. Edwards Books \& Art Ltd. "It is not the role of this Court to devise legislation that is constitutionally valid, or to pass on the validity of schemes which are not directly before it, or to consider what legislation might be the most desirable. ${ }^{137}$ One writer has summarized the Court's attitude this way: ${ }^{38}$

...the Canadian judiciary has demonstrated, and should continue to demonstrate, its fealty to this part of the Constitution Act, 1982. Confidence in the judiciary is well-established in Canada, and rightly so. Indeed, the Courts' recognition of the limits of their role gives rise to at least one basis of granting such confidence. [emphasis] 
The third difference between the Canadian and American judicial/political climate is the Canadian system of court references, in which Parliament and the Legislatures voluntarily seek the advice of the Court. Whereas the American system maintains a strict division between the judicial and executive branches, the Canadian system has never imported such a strict division. The statutory reference system originated in English Common Law and was formally incorporated into the Canadian system in 1875 when the Supreme Court was created. Section 52 of the Supreme and Exchequer Court Act provided for references to the Supreme Court from the Federal Government. Provinces later enacted similar legislation allowing references to provincial courts. Initially references initiated by provinces could only be appealed to the Privy Counsel but, by 1922 , these references could also be appealed to the Supreme Court. ${ }^{39}$ While references were meant to be advisory opinions only as one author notes "it may be seen that at both the federal and the provincial level this device was looked upon as an integral part of the functioning of the constitution". ${ }^{40}$ Even though references had no legal effect, the references from the Supreme Court have always been complied with. The reference tradition thus created an acceptance of the Court's advisory role in constitutional matters and presents an example of a long-standing tradition of communication between the executive and judicial branches.

As a consequence of the factors to which $I$ have referred political/judicial co-operation is not a novel concept in Canada. It is not surprising that it has found application in the post-Charter era. Let me cite some examples.

I cite first the tortured history of Manitoba's Official Language Act. Before the enactment of the Charter the Supreme Court in 1979 found that Manitoba's Official Language Act which permitted statutes to be enacted in English only contravened s. 23 of the British North America Act. ${ }^{41}$ The issue of whether Manitoba laws had to be published in French as well as English had been before the courts many times. The 1890 version of the Act had been ruled ultra vires in 1892 by the County Court of St. Boniface but the decision was never reported and was virtually ignored by the Legislature. ${ }^{42}$ The 1890 Act was again challenged and ruled unconstitutional in 1909, but the decision was also unreported and disregarded. ${ }^{43}$ In 1976, a lower court decision in Forest was again ignored. The Attorney General of Manitoba simply stated "the Crown does not accept the ruling of the Court with respect to the constitutionality of the Official Languages Act..." ${ }^{\text {"4 }}$ The case came before the Supreme Court and the Act was declared ultra vires. Still nothing happened. After the Legislature failed to translate existing statutes or work out a constitutional amendment that would have provided a breathing period in which to

39.

40.

41.

An Act to amend the Supreme Court Act, S.C. 1922, s. 48, s. 1.

Strayer, supra, note 11 at 317.

A. G. Manitoba v. Forest, [1979] 2 S.C.R. 1032, 101 D.L.R. (3d) 385.

Pellant v. Hebert, first published in "Le Manitoba" (a French language newspaper) March 9, 1982. and repored in (1981), 12 R.G.D. 242.

Bertrand v. Dussault, January 30, 1909, County Court of St. Boniface (unreported), reproduced in Re Forest and Registrar of Court of Appeal of Manitoba (1977), 77 D.L.R. (3d) 445 at 458-62, 35 C.C.C. (2d) 497, at 510, [1977] 5 W.W.R. 347 at 361 (Man.C.A.). 
translate the laws, the issue was back before the Court in $1985 .{ }^{45}$ In Re Manitoba Language Rights the constitutional issue was not only the validity of the Manitoba Act but also the issue of whether or not any statutes passed under the invalid Act were invalid. Once again, the Supreme Court declared English-only laws to be unconstitutional. The Court was unprepared, however, to put Manitoba into a state of anarchy by declaring all its laws forthwith unconstitutional. ${ }^{46}$ The solution was a grace period for translation. This time the Manitoba government complied. Although the process took some working out through subsequent appearances before the Court, the final result constitutes an effective example of co-operation between the legislative and judicial branches.

This type of co-operation has continued under the Charter. The Charter's guarantee of democratic rights - the right to vote in particular - illustrates some of the problems which may arise in enforcing judicial pronouncements on rights and reveals an alternative - co-operation between the judicial and legislative branches. As a trial judge in British Columbia, I presided over a trial in which the electoral districting of the Province was challenged. ${ }^{47}$ The plaintiff's case was predicated on the assertion that the existing provincial electoral districts resulted in great disparities of voting power, a vote in certain rural ridings being worth almost forty times a vote in larger urban ridings. I concluded that the right to vote guaranteed by the Charter comprehended, if not exact voter parity, relative equality of voting power having due regard for the difficulties of representation in remote and sparsely populated areas. Applying s. 52 of the Charter, the electoral law, I concluded, was invalid. But the consequences of striking out the statute and leaving the province without any electoral machinery in place in the event an election was required to be called was, I felt, unacceptable. So I adopted the approach of the Supreme Court on the Manitoba statutory reference and said that the electoral law, although unconstitutional, would stay in effect for a specified period of time during which the Legislature could move to replace it with an electoral law that met the requirements of the Charter.

It was not for me, I felt, to dictate to the Legislature what sort of law they should enact; that was the responsibility of the elected representatives. But, again following a time-honoured judicial tradition, I offered advice on what limits on the principle of one person-one vote, might be acceptable.

I decided to defer the really difficult question. What would happen if the Government, which had an obvious interest in maintaining the electoral boundaries as they were, ignored the judgment and did nothing during the time allotted by the Court for reform? Could the Court issue a mandatory injunction to the Legislature to pass the required law? Could the Court substitute a law of its own devising, openly entering into the legislative arena? I did not resolve these questions in my judgment. Instead, I followed the approach which Chief Justice Nemetz had adopted in an earlier case. In that electoral case, the Chief Justice had written:

45. Re Manitoba Language Rights, [1985] 1 S.C.R. 721, 19 D.L.R. (4th) 1.

46. Gibson, supra, note 34 at 186.

47. Dixon v. Attorney General of Rritish Columbia (1989), 35 B.C.L.R. (2d) 273, 59 D.L.R. (4th) 247. 
If any law is inconsistent with the provisions of the Charter, it is the Courts' duty, to the extent of such inconsistency, to declare it to be of no force or effect (s. 52(1)).

Before the Charter, the Courts could and did declare legislation invalid on the division of powers grounds. When they did so, we know of no recent occasion when the legislative branch of government did not faithfully attempt to correct the impugned legislation. Likewise, when this Court declares a statute or portion thereof to be "of no force or effect" where it is inconsistent with the Charter, it is for the Legislature to decide what remedial steps should be taken in view of that declaration. Section 24(1) of the Charter empowers the Courts to grant citizens remedies where their guaranteed rights are infringed or denied ... It would be anomalous, indeed, if such powers were reserved only for cases where limitations are expressly enacted and not for cases where an unconstitutional limitation results because of an omission in a statute. ${ }^{48}$

Chief Justice Nemetz proved right. The Court's call to the Government to correct the defective legislation was heeded in Dixon. The Government moved to introduce legislation in conformity with the Charter and the legislation was promptly passed. The case illustrates how the Court and the Legislature, each acting within the bounds of its proper constitutional responsibilities and each accepting its different constitutional responsibility, can efficaciously resolve a difficult issue. It is too soon to postulate that Canadian Legislatures as a matter of constitutional convention will always respond to judicial decisions striking down legislation by moving promptly to correct the deficiency. But the record to date augurs well.

I turn finally to the decision of the Supreme Court in Mahe. The Court was faced with a difficult quandary. The Legislature had clearly not complied with section 23 of the Charter, given the total absence of representation for minority language schools on the public school board. Striking down the offending portions of the provincial legislation, however, would only have produced a legislative vacuum. The Court was faced with a choice. Should it, itself, draft legislation which would meet the constitutional requirement of s. 23, in effect filling the vacuum, or should it leave the legislation temporarily in place, calling upon the Legislature to do what it should have done in the first place? The Court chose the second alternative. Mindful of a concern not to infringe on legislative functions, the Court set out factors which they deemed should be taken into account and then issued a declaration to the effect that the legislation should be changed to take into account these concerns. In short, the Court instructed the legislators to draft an appropriate law. The use of a general declaration instead of specific instructions, while it may be (and was) criticized as offering insufficient guidance to lower courts, had the merit of allowing the government the flexibility to fashion an appropriate response - a response which may be more sensitive and more appropriate to local concerns than any which a court could fashion. Once again we see a solution predicated on recognition of the complementary roles of the courts and legislatures and on the belief that governments will in good faith comply with court directives. 


\section{CONCLUSION}

There can be no doubt that the Charter poses new and unprecedented problems for the courts, not only in the area of judicial decision-making, but in fashioning remedies which will at once be effective and respectful of the powers of other branches of government. We can follow the route of confrontation, which has so often prevailed in the United States. Or we can continue down the road of mutual deference and cooperation between the judiciary and the legislatures upon which we seem to have embarked, however tentatively. As for me, my hope lies with the latter. 